\title{
Determinant Influencing Factors for Subsidized House Preferences in Bandung Regency
}

\author{
M. R. Andrianto and R. A. Rahadi
}

\section{ABSTRACT}

\begin{abstract}
The increasing population with a limited area of land makes house prices in Bandung City becoming expensive. Many people looking for a cheaper price in the outer city such as in the area around Bandung Regency. It is the largest region and the most populated region that bordered Bandung City. One type of house that is widely offered in the region is subsidized house. It is a house that some of the payment is assisted by the government. The data shows that the subsidized house realization is increasing every year. This research aims to investigate the influencing factor that influences people's preference for the subsidized house in Bandung Regency. Several pieces of literature concludes that the influencing factor for subsidized house preference is price, physical attributes and qualities, accessibility, location, and facility. The methodology used for this research is using quantitative and qualitative studies. The study is using mixed method between quantitative and qualitative method by conducting questionnaires, and interviews. The findings of this research could be useful for the stakeholders such as consumers, governments, and real estate developers. For consumer, this research could be a guide to help the customer find out about their preferences toward the subsidized house. The government could use this research result as guidance and evaluation on their policy. The real estate developers also could use this research to be used as information for their business strategy.
\end{abstract}

Keywords: Preferences, Property, Real Estate, Subsidized house.
Submitted : July 30, 2021

Published : August 21, 2021

ISSN: $2507-1076$

DOI: $10.24018 / \mathrm{ejbmr} .2021 .6 .4 .1002$

M. R. Andrianto*

Master of Business Administration,

School of Business and Management, Institut Teknologi Bandung, Indonesia.

(e-mail: reza_andrianto@sbm-itb.ac.id) R. A. Rahadi

Master of Business Administration, School of Business and Management, Institut Teknologi Bandung, Indonesia.

(e-mail: aswin.rahadi@sbm-itb.ac.id)

*Corresponding Author

\section{INTRODUCTION}

As population growth and urbanization continue, cities are faced with some challenges such as pressure on housing markets [1]. The increasing number of populations create housing problem in the city. Many cities face those problems, one of which is Bandung city. The steady increase in property prices makes it low-income earners harder to own a house in Bandung City, and it is worsening due to the COVID-19 pandemic. So, many people looking for a cheaper price in the outer city such as in the area around Bandung Regency.

One of the most widely offered types of houses is subsidized house. It is a simple and affordable house in which the developers and buyers of the house receives subsidized assistance by the government [2]. The provision of the house is assisted by the government through the ministry of public work and housing by initiating a program called the "1 million housing program". The government help people to own subsidized house by assisting some of its payment of installment and down payment through public work and housing ministerial decree No.42/PRT/M/2015. They also assist the real estate developer who offers the subsidized house by reducing the tax such as income tax and value-added tax through Minister of Finance Regulation no. 113/PMK.03/2014.
The ministry of public work and housing in west java province noted that in 2015, the backlog or the need for proper housing in West Java was 1,225,737 units. However, in 2019 the figure swelled to 1,905,960 units. In term of subsidized house, the data from the ministry of public works and housing's website also shows that the realization of one of government the subsidized house program is increasing every year.

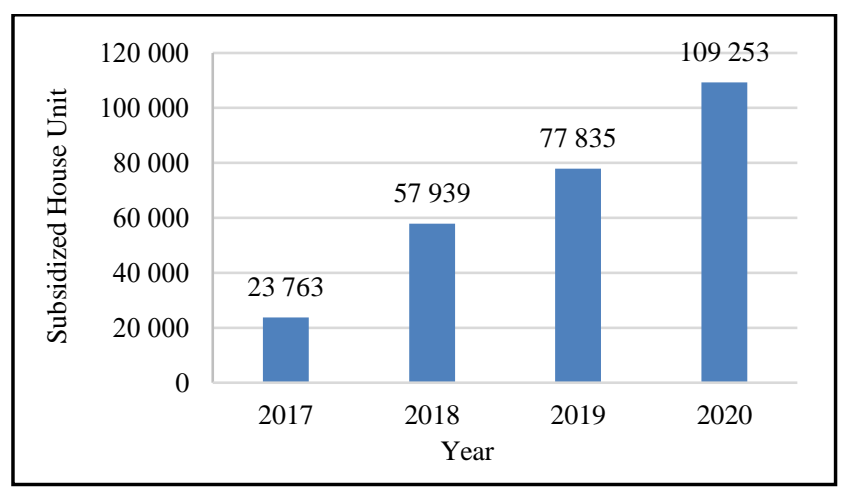

Fig. 1. Realization of FLPP Program 2017-2021 [3].

It shows that the need for the subsidized house is high. So, knowing the preference of subsidized house becomes 
necessary. It also shows that the opportunity of real estate developers to gain profit from selling subsidized houses still consider high. So, to maximize the profit for real estate developers, and also to support the government program. It is better to know the preference on the subsidized house. It aims to find the subsidized housing preference that people desire and need on the market even with the limited price offered. So, real estate developers could know what attributes that people desire and need to maximize sales and compete with other developers. For the government, they could find out what minimum standard of subsidized housing is needed and necessary for the people, evaluate the current program, and fulfill their housing program.

\section{LITERATURE REVIEW}

\section{A. Subsidized House}

In Indonesia, a subsidized house is a simple and affordable house in which the developer of the housing receives subsidized assistance for the construction of public facilities and or social facilities within the housing complex. For a home buyer, they would receive the house price that has been standardized by the government at the market price. If the buyers are using mortgage service to purchases the house, they will receive a fixed interest rate which is the government's policy through the ministry of public works and housing [2].

The subsidized house standard on price or building specification was standardized through regulation of the ministry of public works and housing decree No. 242 / KPTS / M / 2020 which stated that subsidized house maximum price is different in every region. In java island, the current maximum price of the subsidized house is Rp. 150.500.000; with the down payment of $5 \%$ which is lower than the normal standard of $10 \%$.

Based on pembiayaan.pu.go.id, there are several programs that is regulated by the government through Indonesian ministry public works and housing decree regarding the provision of the subsidized house through the ministry of public works and housing which are:

\section{Fasilitas Likuiditas Pembiayaan perumahan (FLPP) Mortgage}

FLPP mortgage is a housing mortgage program provided by the government specifically to assisted low-income people in purchasing a subsidized house which offers an installment mortgage interest rate of $5 \%$ up to 20 years with the downpayment of $5 \%$.

\section{Subsidi Selisih Bunga (SSB) Mortgage}

SSB mortgage program is a homeownership mortgage program issued by the government with a reduction in interest rates which the program is more or less similar as the FLPP program, but the $5 \%$ installment interest rate is only fixed for 10 years,

\section{Bantuan Pembiayaan Perumahan Berbasis Tabungan (BP2BT) Mortgage}

Savings-Based Housing Financing Assistance (BP2BT) mortgage is a financial assistance given by the government to assist the down payment of purchasing subsidized houses by giving cash assistance from 21,4 million IDR up to 32,4 million IDR with 5\% downpayment and normal interest rate.

\section{Subsidi Bantuan Uang Muka (SBUM)}

Down Payment Subsidy (SBUM) is a government subsidy given to low-income people to assist the down payment on purchasing a house by giving cash assistance for 4 million IDR.

\section{B. Consumer Preference}

Consumer preferences as an option like or dislike the person against products (goods or services) are consumed. Consumer preference indicates consumer preferences from a wide selection of products available. Analysis of consumer preferences is an analysis that aims to find out what people likes and dislikes of consumers, as well as to determine the order of importance of the attributes of the product and the product itself [4].

Housing preference is the user's subjective evaluation of housing. It refers to the users' requirements, expectations, and emphasis on the characteristics of various housing [5]. People in different classes may have different expectations for personal and family behavior and housing preferences and choices [6]. Subsidized house which intended to low-income people, they are more concerned with the priority scale of housing locations close to workplaces that have land ownership status, and housing quality [7].

\section{Price Factor}

Price is the amount of money charged for a product or service or the sun of the value that customers exchange for the benefits of having or using the product or service [8]. Price is one of the most influencing factors for the customer's decision-making process when purchasing a product [9]. Continents, countries, and cities differ in factors that determine the residential housing price [10].

In Indonesia, the price of subsidized houses regulated through the ministry of public works and housing decree No. 242 / KPTS / M / 2020. This price varies on every island in Indonesia, with the lowest prices in Java (non-Jabodetabek) and Sumatera (non-Kepri and Babel) of 150.5 million IDR, and the highest in Papua, amounting to 219 million IDR. The interest rate and a down payment rate also regulated which is 5 percent. In this research, the price is categorized into the overall price of the house, the amount of installment, and the amount of downpayment.

\section{Physical Attributes and Qualities Factor}

The physical attributes are the first thing noticed by the consumer when looking for a house [11]. Housing-related attributes of a building had been recognized in the literature as influencing households' buying/renting preferences [12]. attributes such as electricity, water, amount of space, external/internal design, and type of window/ventilation also influence consumer preference [13]. Other research also stated that lot size, number of bedrooms and bathrooms, and presence of garden, and appropriate passive design are the attributes that influence home-buying preferences. Space also has been identified as a leading aspect of the home-buying decision-making process [14].

In Indonesia, the physical attribute of the subsidized house is standardized through public work and housing ministerial decree No. 403/ KPTS / M / 2004, they regulate the physical attribute in various aspects such as the minimum size of the house $21 \mathrm{~m}^{2}$, the land of $60 \mathrm{~m}^{2}$, the wall with the minimum of 
using con-block brick, and other technical regulations. Subsidized housing offers a lower price so that the quality of the subsidized house tends to be below. In this research, the physical attributes \& Qualities are categorized into the number of bedrooms, number of bathrooms, number of kitchens, the house quality (material), house and land size, electricity, and water supply.

\section{E. Accessibility Factor}

Accessibility of a certain location is determined by the easiness to enter and exit the area using a transport system and land-use pattern [15]. The main road, toll road, and access to station or public transportation are the factors that are affecting consumers in making a decision to buy a house in a certain location. Ease of accessibility means that there is more than one access to entrance and exit available to reach the real estate location [16].

On Subsidized houses, access is regulated regarding the road on the ministry of public works and housing decree No. $32 /$ Permen/M/2006 which states that the width of the road is from 3 meters to 6 meters which at least can be passed by 2 cars in opposite directions. Many real estate developers offer different value prepositions regarding the accessibility of the residence which some offers wider access while other less. This research would analyze the accessibility through the easiness of private transportation to get into the housing location, and also the public transport.

\section{F. Location Factor}

The definition of location is where the house is located whether in the city or suburbs [17]. People seek the specific location of the house because they have an intended purpose, such as distance to work, school, or market [18]. Since most of the subsidized house customers are lower-middle-class people. They tend to prioritize work location close distance, or at least closer to land employment [7]. The close distance from housing to medicine, health care facilities, and the hospital also influences the decision-making of buying a property [17]. The better and more strategic location of the house, the demand for the house tends to increase [19]. Indonesians, like most southeast Asians, greatly uphold family values and prefer to live close to their closest family members. It is common for a son and daughter to live with or near their parents or brother and sister [11].

The regulations regarding the housing location is regulated through government regulation no. 12/2021 stated that location should be at least free from the disruption caused by natural disasters such as floods, the risk of land instability (landslides), tsunamis, and hazard radius of volcanic eruptions. Since subsidized housing offers cheaper prices than others, developers have limitations in acquiring lands for a subsidized house so that the locations offered are not all located in strategic areas. In this research, the measurement of location was based on the strategic location by the proximity of the location to the workplace, city center, market, school, health facility, and family relatives.

\section{G. Facility Factor}

Facilities are the housing environment that could offer consumers to enrich the likeliness to live in the developed real estate [20]. From a social point of view, housing is more than a dwelling unit and its characteristics, since it also provides health services, security, privacy, neighborhood and social relations, status, community facilities and services, access to jobs, and control over the environment [18]. The facilities including public facilities and social facilities, including infrastructure, religion, health, transportation facilities, and others [21]. The facility such as children's play area, security, and green space are also the attributes for facilities since the more complete facilities will make real estate more preferable [18].

In subsidized housing, housing facilities are regulated through Government Regulation no. 12/2021 which states that there must be public facilities in every housing at least public facility such as religious facilities, children's playgrounds, sports venues, and road pointerboards, and also green open space. In this study, facilities are measured by security facilities, green space facilities (parks), and religious facilities.

\section{ANALYSIS}

The method in this research is using mixed methods. This method combines quantitative and qualitative research methods. Mixed research is a procedure for collecting, analyzing, and mixing quantitative and qualitative methods in a study or research to understand research problems [22].

In this study, the quantitative method is used through a questionnaire to the people of Bandung Regency to find out their preferences for subsidized housing. The qualitative method was done by conducting interviews with several people that have a stake in subsidized house to find out their preferences in buying subsidized housing according to their view. Based on the author's analysis of the questionnaires and interviews, it shows that some factors are more influenced by the preference of subsidized housing. Due to COVID-19 Pandemic, this research would mostly use online media to spread the questionnaire and do interviews.

\section{A. Quantitative Analysis}

The first analysis is to determine the level of importance of each factor. After the data is obtained, the author ranks the level of importance from the highest to the lowest that affects the preference of subsidized housing. The results indicate that the level of importance of the main factor rankings is as follows:

1. Price;

2. Physical Attribute and Quality;

3. Facility;

4. Location;

5. Accessibility.

In this study, the authors not only wanted to find information in general about the related factors that influence people in buying subsidized houses but also in detail about each of these factors through several sub-factors. In addition to ranking results from the level of importance of the main factors, the authors also rank the importance of the subfactors related to each main factor that affects the preference for subsidized houses in Bandung Regency. The following are the results of the subfactor rankings from the data that has been analyzed by the author.

a) Price:

\section{Affordable Price;}


2. Affordable Loan Installments;

3. Affordable Down Payment;

b) Physical Attribute \& Qualities:

1. Adequate water \& electric supply;

2. Adequate number of Bedroom, Bathroom \& Kitchen

3. High-Quality Material;

4. Big land and house size;

c) Accessibility:

1. Easy access by private transportation;

2. Easy access by public transportation;

d) Location:

1. Close to public Facility (School / Hospital);

2. Close to Workplace;

3. Close to City center;

4. Close to Family / Relatives;

e) Facility:

1. Religious Facility;

2. Security Facility;

3. Playground Facility;

The next analysis is based on questionnaire data where respondents rank the highest to lowest factors that affect respondent's preference in subsidized housing. The rank of the main factor shows the different results from the next analysis conducted by the author. The results obtained are as follows :

1. Price;

2. Location;

3. Physical Attributes and Qualities;

4. Accessibility;

5. Facilities.

Although the two results above show differences in rankings, the main factors that influence the preference for subsidized housing remain the same. Both results show that price is the most influential factor that affects the preference for subsidized houses. This is similar to previous research conducted where price and location are the main factors that influence people's preferences in buying a subsidized house after examining the consumers in several subsidized housing in Kerawang City [2]. Other research also shows the same result which price is the most important considerations for people with low earners when looking for a house where they mostly expect a low down payment and installments [23].

\section{B. Qualitative Analysis}

Regarding the price, Interviewee consider it as the most important factor than the rest. Most respondents still prefer the lowest price even though the maximum price of a subsidized house standardized by the government is already low. It happens since the price of the subsidized house differs in every subsidized housing since each offers a different value proposition. In terms of the price attribute, most respondents prefer the current overall price is maintained only the amount of loan installment and the down payment is better be reduced.

Physical attributes and housing qualities are important in buying a subsidized house. The feasibility of the housing is considered are the most important since they mostly concern about its quality, and wanted to make sure that the house is safe to be lived. The material of the house should be adequate and strong with some even said that they wanted the house made from Hebel / red brick since some of them are using low quality of brick.

Most respondents said that the most important access was the main road access provided by the developer. Many of them expect wide road, good quality of the road, and the road that not easily damaged. The results of the interview show that most of the respondents do not use public transportation so that access to public transportation is not entirely important. Ease of access for private transportation is considered more important because people are more likely to use private transportation.

Location considered the most important in buying a subsidized house after the price This is because a good location could help people to easily carry out their daily activities. Based on interviews, there are differences in measuring how strategic the location of housing is, but most of the respondents said that the most important location was the location that closes to public facilities such as schools, and hospitals. Some also said that the location is better if it is close to the city center. Few people said that the location should be close to the workplace, close to public transportation, and free from flood.

Facilities is important in buying subsidized housing. Majority of respondents said that the religious facility should be found in subsidized housing. This is because most of the respondents are likely to be Muslims which is the same religion as most of the Indonesian people. The mosques are considered important to fulfill their religious needs, and also because there are several events in which Muslims carry out their activities in mosques. Therefore, the mosque is the most important facility factor even though some people want other facilities such as security, parks, and sports facilities.

\section{CONCLUSIONS}

Based on the analysis, it is concluded that all the factor which is price, physical attributes and qualities, accessibility, location, and facility is consider important by the respondents. Price is considered as the most influential factor on the preference of subsidized housing than the rest.

The findings of this research could be used by the stakeholder of the subsidized house such as the consumers. They should be careful in choosing the subsidized house where consumers should look at several aspects before buying a subsidized house such as price, location, and house quality. those factors should be following the standard regulations on the subsidized house that already determined by the government.

In addition, the government as the provider of subsidized house could also benefits from this research where they could evaluate the policies related to subsidized house especially the beneficiaries so that the benefits could be given to those who are entitled to receive them, and the developers are following the existing regulations.

Furthermore, developers could use the results of the analysis where subfactor rankings of each main factor have their priority. These results indicate that with all the limitations offered by the developer on a subsidized house, the management could maximize several attributes even though they have to sacrifice several other attributes so that they can be used as the value proposition on the subsidized house offered. 
The further research could use other factor to better determine the housing preferences for the subsidized house market. The next research should also examine people's preferences for subsidized housing in other regions. It is intended to know the factors that influence overall people's preferences for the subsidized house in Indonesia.

\section{REFERENCES}

[1] Van Doorn, L., Arnold, A., \& Rapoport, E. (2019). In the age of cities: The impact of urbanisation on house prices and affordability. In Hot Property (pp. 3-13). Springer, Cham.

[2] Antony, B. (2017). Preferensi konsumen terhadap faktor-faktor penentu kepuasan konsumen dalam pengambilan keputusan pembelian perumahan bersubsidi di Karawang, Studi kasus: Perum Bhumi Baru Indah Persada, Perum Taman Palumbon Asri, Perum Griya Indah Cikampek (Doctoral dissertation, Universitas Tarumanagara).

[3] Realization of FLPP program 2017 - 2020. (2020). Retrieved from https://ppdpp.id/realisasi-dashboard/.

[4] Kotler, P. (2010). Marketing Management. Prentice Hall.

[5] Jun, H. J., Kim, J. H., Rhee, D. Y., \& Chang, S. W. (2020). "SeoulHouse2Vec": An embedding-based collaborative filtering housing recommender system for analyzing housing preference. Sustainability, 12(17), 6964.

[6] Beamish, J. O., Carucci Goss, R., \& Emmel, J. (2001). Lifestyle influences on housing preferences. Housing and Society, 28(1-2), 1-28.

[7] Turner, John F.C.1972. Housing By People. Marion Boyars Publisher Ltd. London.

[8] Kotler, P., \& Armstrong, G. (2013). Principles of Marketing (16th Global Edition).

[9] Purwanegara, M. S., \& Rahadi, R. A. (2017). Stimulus Choice: What We Have Learned So Far. Journal of Globe Business and Social Entrepreneurship, 1(3), 164-192.

[10] Wittowsky, D., Hoekveld, J., Welsch, J., \& Steier, M. (2020). Residential housing prices: impact of housing characteristics, accessibility and neighbouring apartments-a case study of Dortmund, Germany. Urban, Planning and Transport Research, 8(1), 44-70.

[11] Rahadi, R. A., Wiryono, S. K., Koesrindartoto, D. P., \& Syamwil, I. B. (2015). Factors influencing the price of housing in Indonesia. International Journal of Housing Markets and Analysis.

[12] Opoku, R. A., \& Abdul-Muhmin, A. G. (2010). Housing preferences and attribute importance among low-income consumers in Saudi Arabia. Habitat international, 34(2), 219-227.

[13] Otegbulu, A. C., Osagie, J. U., \& Famuyiwa, F. (2009, September). A Value Hierarchy Study of Building Services/Components in Commercial and Residential Developments: A Comparative Analysis. In Proceedings of the $25^{\text {th }}$ Annual Conference of Association of Researchers in Construction Management (pp. 7-9).

[14] Clark, W., \& Onaka, J. (1983). Life Cycle and Housing Adjustment as Explanations of Residential Mobility. Urban Studies, 20(1), 47-57.

[15] Zondag, B., \& Pieters, M. (2005). Influence of accessibility on residential location choice. Transportation Research Record, 1902(1), 63-70.

[16] Smersh, G. T., \& Smith, M. T. (2000). Accessibility Changes and Urban House Price Appreciation: A Constrained Optimization Approach to Determining Distance Effects. Journal of Housing Economics, 9(3), 187-196.

[17] Olanrewaju, A., \& Woon, T. C. (2017). An exploration of determinants of affordable housing choice. International Journal of Housing Markets and Analysis.

[18] Mulyano, Y., Rahadi, R. A., \& Amaliah, U. (2020). Millennials Housing Preferences Model in Jakarta. European Journal of Business and Management Research, 5(1).

[19] Awang Firdaos. 1997. "Permintaan dan Penawaran Perumahan". Jurnal Survey dan Penilaian. Vol. 007. Jakarta.

[20] Churchman, A. (1999). Disentangling the Concept of Density. Journal of Planning Literature, 13(4), 389-411.

[21] Widiastuti, E., \& Handayani, S. (2013). Analisis Faktor-Faktor yang Mempengaruhi Keputusan Pembelian Rumah Bersubsidi dengan Menggunakan Analisis Regresi. In Prosiding Seminar Nasional Statistika Universitas Diponegoro. Fakultas Ekonomi, Universitas Diponegoro. Semarang.

[22] Creswell, J. W. (2018). Qualitative inquiry et research design: choosing among five approaches. Los Angeles; London; New Delhi; Singapore; Washington DC: SAGE.

[23] Rahmadaniyati, D., Faqih, M., \& Hayati, A. (2016). Housing Preference for Low-Income People in Indonesia. In Proceeding"
Enhancing Academic Collaboration Through ASEA-UNINET Scientific Meeting.

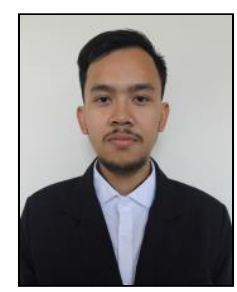

M. R. Andrianto has working experience for 2 (two) years in construction and real estate company. Holds a bachelor's degree in accounting from Widyatama University.

He currently works as an accounting staff in a real estate developer that builds subsidized housing in West Java Province around Bandung Regency and Sukabumi Regency.

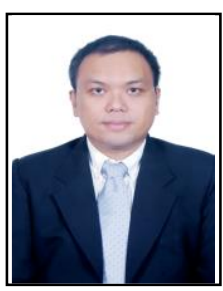

R. A. Rahadi has direct experience working for 15 (fifteen) years in real estate, property, architecture, design, investment management, financial consulting, and research industry. Holds a bachelor degree in Architecture Engineering from Bandung Institute of Technology, hold two master degrees in Management from Swiss German University, Indonesia and in Business Administration from Fachhochschule Konstanz - Hochschule für Technik, Wirtschaft und Gestaltung, Germany, holds a Doctorate in Management Science from School of Business and Management, Bandung Institute of Technology.

Holds Qualified Wealth Planner (QWP (B) certification from IAFP Global, International NLP Basic Practitioner Certificate from National Federation of Neuro-Linguistic Programming (NFNLP), and Registered Financial Associate (RFA $\left.{ }^{\circledR}\right)$ Certificate from International Association of Registered Financial Consultants. 